\title{
Using Stated Preference Techniques to Value Four Key Ecosystem Services \\ on New Zealand Arable Land
}

\author{
Yuki Takatsuka* \\ Economics Department \\ Temple University Japan Campus \\ 4-1-27 Mita, Minato-ku, Tokyo 108-0073, Japan \\ Tel +81-3-5441-9800 \\ Ytakatsu@temple.edu \\ Ross Cullen \\ Faculty of Commerce, Lincoln University \\ PO Box 84, Canterbury, New Zealand \\ Tel +64-3-325-3807 \\ Ross.cullen@lincoln.ac.nz \\ Matthew Wilson \\ Climate Change Services \\ Industrial Systems Business \\ CH2MHILL \\ 9191 South Jamaica Street \\ Englewood, CO. 80112, USA \\ Tel +1-720 286-1811 \\ Matthew.Wilson2@CH2M.com \\ Steve Wratten \\ Bio-Protection Research Centre \\ Lincoln University \\ PO Box 84, Canterbury, New Zealand \\ Tel+64-3-325-2811 \\ Steve.wratten@lincoln.ac.nz
}

* Corresponding author 
Abstract: Many researchers have noted that not only natural ecosystems but also landscapes actively modified by humans (engineered or designed ecosystems) can significantly impact the level of ecosystem goods and availability of services thereby impacting human and social welfare. In New Zealand, agricultural lands are the largest area of engineered ecosystems on the national landscape. Study of the welfare effects of ecosystem services delivered by agricultural land can provide important insights into the management of engineered or designed ecosystems. This paper uses the contingent valuation method (CVM) and choice modeling to estimate values of four key ecosystem services, climate regulation, water regulation, soil retention and scenic views, for New Zealand land used for arable farming,

Key Words: Environmental Valuation, Choice Modeling, Contingent Valuation Method, Ecosystem Services, Arable Farming 


\section{Introduction}

Not only natural ecosystems but also landscapes actively modified by humans (engineered or designed ecosystems) can significantly impact the level of ecosystem goods and availability of services thereby impacting human and social welfare. In New Zealand, agricultural lands are the largest area of engineered ecosystems on the national landscape. Study of the welfare effects of ecosystem services (ES) delivered by agricultural lands can provide important insights into the management of engineered or designed ecosystems.

Farmers use a variety of inputs including labour, machinery, diesel, seeds, and fertilizer, to produce food, fiber or raw materials. In addition to these inputs, they also make use of natural capital inputs such as soil fertility, pollination, bio-protection, and groundwater. The latter inputs are examples of ES. Researchers have classified ES into four categories: regulating, supporting, provisioning, and cultural services (Millennium Ecosystem Assessment, 2003). Food, fiber and raw materials are examples of provisioning ES. Several authors have noted that ES play major roles in supporting or contributing directly to economic output including that from agriculture (Costanza, et al., 1997; Daily, 1997; Heal and Small, 2002; Moonen and Barberi, 2008). It is clear that agriculture both benefits from and produces ES.

Income generation is a key objective for the majority of New Zealand farmers. Production of food, fiber and raw material generates revenue for landowners, as food and fiber outputs can be sold in the market place. However, many ES delivered by farms have public good characteristics. There are no markets for such ES and hence no prices to users or revenue for producers of those ES. The absence of property rights for ES can result in their importance being overlooked by decision makers. When that occurs, profit maximizing behavior may not lead to welfare maximization. Under these conditions, farmers may apply high levels of external inputs such as synthetic fertilizer, pesticides, irrigated water and other inputs if they focus on food or fiber production to achieve short term profit maximization. This focus on profit maximization may have harmful consequences for natural capital stocks such as 
water quality, soil quality, air quality and future productivity of the land. Little attention may be focused by landowners on aesthetic qualities of the landscape, or recreation possibilities if these ES are not readily marketed.

In many high income countries, agriculture has become more intensive in the last few decades (Pretty, et al., 2003; Parliamentary Commissioner for the Environment, 2004; Glendining, et al., 2008). In New Zealand the intensification of agriculture has raised concerns about some of the harmful effects it can have including high nitrate levels in groundwater, degradation of lowland streams and lakes, decrease in fish availability and increase in greenhouse gas emissions (Hughey, et al., 2004; Parliamentary Commissioner for the Environment, 2004; NIWA, 2007). These concerns have focused particularly on dairy farming but other types of farming including arable farming have come in for attention (Pyke, 2008). Arable land in New Zealand produces wheat, barley, maize and other seed crops. The yields of these products have been growing sharply in the last decade. The national average wheat yield increased by $37 \%$ during 1992 - 2003, and maize grain production increased by $15 \%$ in the same period (MAF Policy, 2009). In the same time frame, arable farming in New Zealand has increased the use of nitrogenous fertilizers, which has led to the increase in greenhouse gas emissions and leaching of nitrates into the groundwater. Moreover, conventional arable farming practices lead to losses of soil through wind and water erosion and tends to mine soil organic matter. There are few recreation opportunities on conventional arable farms and arable farming landscapes may provide little aesthetic interest if they are dominated by treeless monocultures.

Past studies have estimated the total economic value of ES globally from 16 biomes (Costanza, et al., 1997). Average, but not marginal values per hectare, of each ES have been estimated in these studies and the average values per hectare are applied irrespective of location. Patterson and Cole (1999a; 199b) replicated the Constanza et al. (1997) study and estimated values for Waikato and New Zealand ES. The land cover classes used in the Waikato and New Zealand studies include horticulture, agriculture and cropping land. Patterson and Cole (1999a; 1999b) report that on arable land only five ES have positive economic values. 
We contend that arable farming can provide a range of ES and benefits to society. Although ES are non-marketed commodities and rarely measured, researching the values of ES could identify strategies for sustainable production on arable lands, which are engineered or designed ecosystems. The objective of this paper is to review methods to accurately measure the value of non-marketed ES associated with arable farming. In our study, we consider two techniques, the contingent valuation method (CVM) and choice modeling, to estimate the values of selected ES provided on New Zealand arable land. Our paper estimates the welfare values associated with four key ES: climate regulation, water regulation, soil retention, and scenic views associated with arable lands such as wheat, barley, maize, and other seed crops. Based on the data collected in a nationwide mail survey, our study reveals New Zealand resident's willingness to pay for improvements in these ES and establishes "ideal" levels for these attributes. We comment on the likelihood that private sector arable farming in New Zealand will shift toward farming that will maximize the sum of ES.

\section{CVM and Choice Modeling Theory}

In this study, our primary aim is to assess marginal economic values of ES; hence we employ two stated preference techniques - CVM and choice modeling. These two techniques have become more acceptable in recent years to estimate magnitudes for willingness to pay for improvements in environmental qualities (Haab and McConell, 2003). Choice modeling is basically a modification of CVM. The similarity between the two models is that questions to survey respondents are based on hypothetical scenarios. However, choice modeling claims to have greater accuracy with regard to the characteristics used to describe an event. While CVM asks individual about a single event or outcome, choice modeling asks them to choose their preferred option from a "choice set" founded on different configurations of multiple events or outcomes. Each configuration consists of a different set of attributes. The key advantage of using choice modeling over CVM is that the method does not rely on a specific case of environmental change (Boxall, et al., 1996). Rather, it relies on multiple attributes in a choice situation. Another advantage of choice modeling is its experimental aspects (Boxall, et al., 
1996). Individuals choose one event among several options having a variety of attributes. Thus, individuals consider tradeoffs among the attributes, and the tradeoffs are reflected in their choice.

CVM and choice modeling are formulated in a random utility framework, which allows measurement of the values of non-market goods and services. The utility function (U) is composed of an observable component $\mathrm{V}$ (indirect utility function) and an unobservable stochastic error component $\varepsilon$ :

$$
U=V+\varepsilon
$$

We assume that the indirect utility is a linear form,

$$
V_{i}=\beta_{k i} X_{k i}+\alpha_{i} y_{i}=\beta_{0}+\beta_{1 i X 1 i}+\beta_{2 i X 2 i}+\beta_{3 i X} X_{3 i}+\ldots+\beta_{k i} X_{k i}+\alpha_{i} y_{i}
$$

where $X_{k i}\left(=\left\{\mathrm{x}_{1 \mathrm{i}}, \mathrm{x}_{2 \mathrm{i}}, \ldots, \mathrm{x}_{\mathrm{ki}}\right\}\right)$ is vector of $\mathrm{k}$ attributes associated with alternative $\mathrm{i}, \beta$ is a coefficient vector, $y_{i}$ is income for a respondent choosing the alternative i bundle, and $a$ is the coefficient vector of income. If the stochastic error term is logistically Gumbel distributed (Type I extreme value distributed), the choice probability for alternative $\mathrm{i}$ is given by,

$$
\operatorname{Pr}(i)=\frac{\exp \left(\rho V_{i}\right)}{\sum_{j \in C}^{J} \exp \left(\rho V_{j}\right)}
$$

where $\rho$ is a positive scale parameter, and $\mathrm{C}$ is the choice set for an individual. For convenience we generally make the assumption $\rho=1$ (Ben-Akiva and Lerman, 1985).

To estimate the welfare impacts, i.e., willingness-to-pay, for a change from the status quo state of the world to the chosen state, the following formula is used: 


$$
V_{i}\left(X_{i}, y\right)+\varepsilon_{i}=V_{j}\left(X_{j}, y-C V\right)+\varepsilon_{j}
$$

where $V_{i}$ and $V_{j}$ represent utility before and after the change and $\mathrm{CV}$ is compensating variation, the amount of money that makes the respondent indifferent between the status quo and the proposed scenario.

A multinomial logit model or conditional logit model can be applied to estimate the welfare measure in equation (4). With the multinomial logit model, the effects of the attribute variables are allowed to differ for each outcome. Equation (4) can be restated as:

$$
\beta_{k i} X_{k i}+\alpha_{i} y+\varepsilon_{i}=\beta_{k j} X_{k j}+\alpha_{j}(y-C V)+\varepsilon_{j}
$$

$\alpha_{\imath}$ and $\alpha_{j}$ are assumed to be equal (Haab and McConnell, 2003) if marginal utility of income for a respondent is constant. The welfare change is estimated by:

$$
C V=-\frac{1}{a}\left[\left(\beta_{k i} X_{k i}-\beta_{k j} X_{k j}\right)+\left(\varepsilon_{i}-\varepsilon_{j}\right)\right]
$$

For the multinomial logit model, the coefficient vector of $\mathrm{k}$ attribute variables differ for each alternative, and $\beta_{k i} \neq \beta_{k j}$. Alternatively, in the conditional logit model, coefficients of $\mathrm{k}$ attributes across all the alternatives are the same (Greene, 2005), and $\beta_{k i}=\beta_{k j}$; only the attribute levels differ across the alternatives. Under this condition, welfare change is estimated by the following:

$$
C V=-\frac{1}{a}\left[\beta_{k}\left(X_{k i}-X_{k j}\right)+(\varepsilon i-\varepsilon)\right]
$$


In this paper, the conditional logit model (equation 7) is used to estimate welfare changes in ES, since the impact of the attributes of ES is assumed to remain the same across all choice alternatives.

\section{Survey Experiment Methodology}

In September 2004, pilot surveys were tested on students at Lincoln University and on randomly selected residents in both the South and North Island. Because of the complexity of our survey instrument, we asked participants in the pilot survey how readily they understood the survey questions. More than $80 \%$ of the pilot survey participants stated that they could easily understand the survey questions. In November 2004 a pre-survey card, survey booklet and cover letter, and a reminder postsurvey card were sent to 3000 individuals selected from the New Zealand electoral roll using a random stratified sampling design. The sample was divided into two strata: 1500 persons were randomly selected from the Canterbury region (which contains the largest area of arable farming in New Zealand) and 1500 from the rest of New Zealand. As the survey experiment was designed to use both CVM and choice modeling techniques, two different survey formats, CVM and choice modeling were designed and 480 CVM surveys and 1020 choice modeling surveys were mailed to each stratum.

The response rates for the surveys are shown in Table 1. The overall effective response rate for the survey experiment was $36 \%$. The response rate to the CVM survey was $35 \%$ in both regions. For the choice modeling survey it was $39 \%$ in Canterbury and $34 \%$ in the rest of NZ.

Table 1. Response Rates

\begin{tabular}{|c|c|c|c|c|c|c|c|}
\hline & \multicolumn{3}{|l|}{ Canterbury } & \multicolumn{3}{|l|}{ Rest NZ } & \multirow[t]{2}{*}{ Total } \\
\hline & CVM & CHOICE & Subtotal & CVM & CHOICE & Subtotal & \\
\hline Surveys & 480 & 1020 & 1500 & 480 & 1020 & 1500 & 3000 \\
\hline Undelivered & 15 & 20 & 35 & 17 & 31 & 48 & 83 \\
\hline Responded & 163 & 391 & 554 & 160 & 334 & 494 & 1048 \\
\hline Response Rate & 0.35 & 0.39 & 0.38 & 0.35 & 0.34 & 0.34 & 0.36 \\
\hline
\end{tabular}


Both the CVM and choice modeling surveys contained four sections: (1) general questions about the environment in New Zealand; (2) general questions about New Zealand farming; (3) specific questions about alternative management scenarios for cropping farming; and (4) questions about respondent's social characteristics and backgrounds. Except for the section on alternative scenarios for cropping farming, all questions were held constant between the two formats. Social characteristic questions asked respondents about their age (AGE), gender (GENDER), education (EDU), income (INC), and residence in rural or urban area (UEB). The questions relating to the environment and farming are summarised in Table 2 with the relevant variable names.

Table 2. Definitions of Variables

\begin{tabular}{|c|c|}
\hline Variables & Definitions \\
\hline AGE & Age \\
\hline GENDER & 1 if male; 0 if female \\
\hline EDU & $\begin{array}{l}1 \text { if primary school; } 2 \text { if high school without qualifications; } 3 \text { if high school with qualifications; } 4 \text { trade/technical } \\
\text { qualification; } 5 \text { undergraduate diploma; } 6 \text { bachelors degree; } 7 \text { postgraduate }\end{array}$ \\
\hline INC & $\begin{array}{l}5 \text { if less than } \$ 10,001 ; 15 \text { if } \$ 10,001 \text { to } \$ 20,000 ; 25 \text { if } \$ 20,001 \text { to } \$ 30,000 ; 35 \text { if } \$ 30,001 \text { to } \$ 40,000 ; 45 \text { if } \$ 40,001 \text { to } \\
\$ 50,000 ; 55 \text { if } \$ 50,001 \text { to } \$ 60,000 ; 65 \text { if } \$ 60,001 \text { to } \$ 70,000\end{array}$ \\
\hline URB & 1 if residence in urban area; otherwise 0 \\
\hline ENVIS & Knowledge of environmental issues; 1 if don't know; 2 if very bad; 3 if bad; 4 if adequate; 5 if good; 6 if very good \\
\hline AIR & Quality of New Zealand air: 1 if don't know; 2 if very bad; 3 if bad; 4 if adequate; 5 if good; 6 if very good \\
\hline FWAT & $\begin{array}{l}\text { Quality of New Zealand freshwater in rivers and lakes: } 1 \text { if don't know; } 2 \text { if very bad; } 3 \text { if bad; } 4 \text { if adequate; } 5 \text { if good; } 6 \\
\text { if very good }\end{array}$ \\
\hline GWAT & Quality of New Zealand groundwater: 1 if don't know; 2 if very bad; 3 if bad; 4 if adequate; 5 if good; 6 if very good \\
\hline CWAT & Quality of New Zealand coastal water: 1 if don't know; 2 if very bad; 3 if bad; 4 if adequate; 5 if good; 6 if very good \\
\hline SOIL & Quality of New Zealand soils: 1 if don't know; 2 if very bad; 3 if bad; 4 if adequate; 5 if good; 6 if very good \\
\hline PEST & $\begin{array}{l}\text { Compared with five years ago New Zealand pesticides and fertilizer management in agriculture; } 1 \text { if don't know; } 2 \text { if } \\
\text { much worse; } 3 \text { if worse; } 4 \text { if no change; } 5 \text { if better; } 6 \text { if much better }\end{array}$ \\
\hline GG & $\begin{array}{l}\text { Compared with five years ago New Zealand greenhouse gas emission management; } 1 \text { if don't know; } 2 \text { if much worse; } 3 \\
\text { if worse; } 4 \text { if no change; } 5 \text { if better; } 6 \text { if much better }\end{array}$ \\
\hline
\end{tabular}




\section{$\underline{\text { ES characteristics and attributes }}$}

The attributes of selected ES provided by arable farming in New Zealand were explained to all survey respondents at the beginning of the section on alternative scenarios. Attributes discussed were greenhouse gas emissions, nitrate leaching, soil retention, and scenic views of cropping farms. The background information on cropping farming explained to respondents in the survey is as follows:

Synthetic nitrogen fertilizers used on cropland create greenhouse gas emissions and water contamination. Soils where excess nitrogen fertilizer has been used release greenhouse gases into the air, which speeds up climate change, and nitrate leaching from the soil lowers the quality of freshwater in streams and lakes and can pose a threat to human health.

Nitrogen fertilizer use is 10 times greater than it was a decade ago and is expected to continue increasing. Improved management of nitrogen fertilizer use on cropping land and less cultivation can reduce its harmful impacts. Scientists and researchers have found that controlling the amount, timing, and location of fertilizer use will reduce levels of greenhouse gas emissions and nitrate leaching to freshwater.

Continued cropping over many years can lead to reduced organic matter levels in soil and damaged soil structure. It can also expose soils to wind and water erosion. More than 25 years can be required to reverse the soil losses caused by water erosion. Changing crop rotation and periods of pasture can help to maintain soil quality and reduce erosion.

Scenic views are important to many people. Some cropping landscapes contain only post and wire fences, no trees, no hedges, and few crop varieties. Others have a range of crop types and hedgerows, which provide more variety of scenery including more birds and trees. 
Following the above information, the survey provided respondents a scenario in which regional governments aimed to enhance the sustainability of cropping farming. In the scenario, policy focused on greenhouse gas emissions, water quality, soil quality and scenic views of cropping farms, which were the four targeted environmental attributes in our study. Then a series of feasible environmental outcomes from policy options were presented to the respondents. The survey explained to respondents that the outcomes were reasonable future states of cropping farms.

Since our study aimed to determine which environmental attributes are most important to respondents, each outcome from a policy option contains the four environmental attributes and the ranges of these attributes. Each attribute was presented to respondents as several discrete levels of delivery (see Table 3). For example, the attribute of greenhouse gas emissions from cropping farms was presented as having three discrete levels: 'big reduction' (50\% reduction from the current emission level); 'small reduction' (20\% reduction from the current emission level); and 'no change' from current emission levels. For the nitrate leaching from cropping farms, there were three levels presented to respondents: 'big reduction' (50\% reduction in nitrate leaching to streams); 'small reduction' (20\% reduction in nitrate leaching to streams); and 'no change' from current level of nitrate leaching to streams. The attribute of soil quality on cropping farms was limited to two levels: 'small change' (soils retain their organic matter and structure over 25 years) and 'no change' (continuation of the current slow rate of soil degradation). The fourth attribute, scenic views of cropping farms was also limited to two levels; 'more variety' (more trees, hedgerows and birds and a greater variety of crops on cropping farms) and 'no change' (maintain the current cropping farming landscape). Two attributes, soil quality and scenic view, do not provide quantitative changes in level. However, using effect codes allows our study to estimate the economic value of each attribute in a quantitative way, as is explained in more detail in section 6 (Table 6). 
Table 3. Definitions of Attributes on Arable Farms

\begin{tabular}{lll}
\hline Attributes & Levels & Definitions \\
\hline Greenhouse Gas Emissions & Big Reduction & $50 \%$ reduction from the current emission level \\
\cline { 2 - 3 } & Small Reduction & $20 \%$ reduction from the current emission level \\
\cline { 2 - 3 } & No Change & Maintain current emission level \\
\hline & Big Reduction & $50 \%$ reduction in nitrate leaching to streams \\
\cline { 2 - 3 } & Small Reduction & $20 \%$ reduction in nitrate leaching to streams \\
\hline Soil Quality & Small Change & $\begin{array}{l}\text { Soil organic matter and structure are retained over 25 } \\
\text { years }\end{array}$ \\
\cline { 2 - 3 } & No Change & Maintain current slow rate of soil degradation \\
\hline Scenic Views & More Variety & $\begin{array}{l}\text { More trees, hedgerows and birds and a greater variety of } \\
\text { crops on cropping farms }\end{array}$ \\
\cline { 2 - 3 } & No change & Maintain the current cropping farm landscape \\
\hline Cost to Household & $\begin{array}{l}\text { Annual payment to a regional council for the next } 5 \text { years } \\
\text { (NZ } \$ \text { ) }\end{array}$ \\
\hline
\end{tabular}

\section{$\underline{\text { CVM and choice modeling formats }}$}

In the CVM survey $(n=480)$, respondents were asked to choose one hypothetical policy option from two alternative scenarios (See Appendix A). The first scenario involved a 'big reduction' in levels of greenhouse gas emissions, but 'no change' in the other three attributes, and a specific \$ amount charged to each household. The other scenario had 'no change' in all four attributes with no charge to a household.

The cost to the household, the payment vehicle, was defined as an additional annual payment to the regional council responsible for management of the environment over the next five years. The discrete range of cost alternatives given to respondents was NZ\$10, $\$ 30, \$ 60$, and $\$ 100$. As the CVM survey questionnaires were designed to contain only one dichotomous CVM question, four different versions of the CVM surveys were created, one for each cost alternative. For all CVM versions, open-ended questions were asked after the dichotomous questions for the first scenario. After these two questions, the respondents were asked for their ideal policy; ideal level of each attribute; and their willingness-topay for the ideal combination.

In the choice modeling surveys $(\mathrm{n}=1020)$, more complex questions were asked about alternative policies for cropping faming. As in the CVM surveys, before the choice questions, respondents were 
briefed about the four attributes of ES and associated cost to the household. In the choice questions, however, respondents were asked to select the option they favored the most out of the three options provided (See Appendix B). Each option contained the four attributes and the cost to the household with various levels of attribute combinations. Policy option 1 had a higher cost to the household than did Policy option 2, and Policy option 3 was designed as the status quo. Respondents were asked to answer similar types of choice questions (the choice set) multiple times. As there are three levels for the greenhouse gas emission and nitrate leaching attributes, two levels in the soil and scenic view attributes, and four levels in the cost to household, there are $2^{2} \times 3^{2} \times 4$ factorial designs (Louviere, et al., 2000). For statistically efficient choice designs, a D-efficient design excluding unrealistic cases was adapted to each of the choice questions (Huber and Zwerina, 1996; Terawaki, et al., 2004). Following the choice set questions, respondents were questioned about their ideal policies.

\section{Results}

The descriptive statistics of the four sample strata (choice modelling in Canterbury, choice modelling in the rest of New Zealand, CVM in Canterbury, CVM in the rest of New Zealand) are presented in

Table 4.

Table 4. Descriptive Statistics

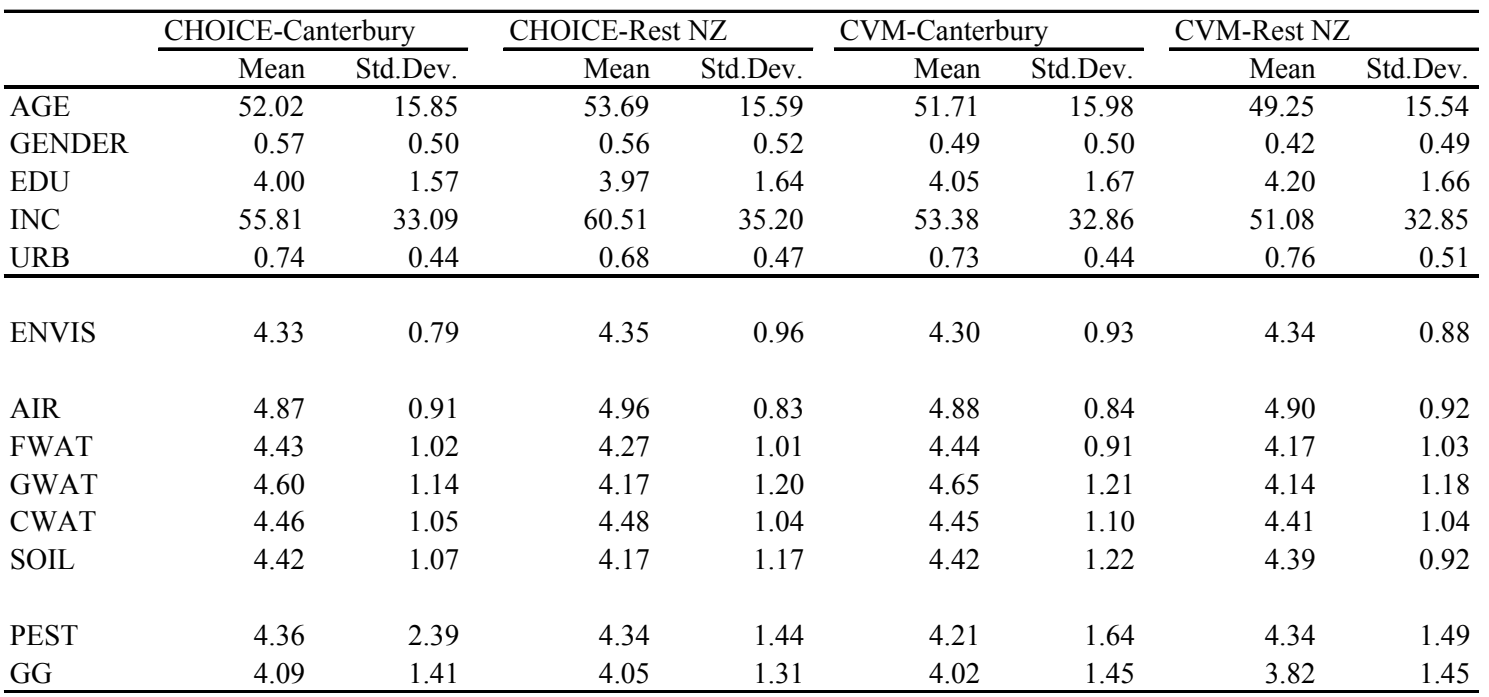


Table 5. Binomial Logit: CVM

\begin{tabular}{|c|c|c|c|c|c|c|c|c|}
\hline & \multicolumn{4}{|l|}{ Canterbury } & \multicolumn{4}{|l|}{ Rest of NZ } \\
\hline & Coeff. & Std.Err. & t-ratio & P-value & Coeff. & Std.Err. & t-ratio & $\mathrm{P}$-value \\
\hline CONSTANT & $0.628 * *$ & 0.295 & 2.128 & 0.033 & $1.324 * *$ & 0.313 & 4.232 & $2.32 \mathrm{E}-05$ \\
\hline COST & -0.003 & 0.005 & -0.645 & 0.519 & $-0.015 * *$ & 0.005 & -2.928 & 0.003 \\
\hline Number of observation & 151.000 & & & & 154.000 & & & \\
\hline Log likelihood function & -100.364 & & & & -95.928 & & & \\
\hline Log likelihood function (0) & -100.572 & & & & -100.371 & & & \\
\hline Chi-squared & 0.416 & & & & 8.885 & & & \\
\hline Significances & 0.518 & & & & 0.003 & & & \\
\hline McFadden & 0.002 & & & & 0.044 & & & \\
\hline Ben/Lerman & 0.528 & & & & 0.568 & & & \\
\hline Akaike I.C. & 1.356 & & & & 1.272 & & & \\
\hline $\begin{array}{l}* \text { Significant at the } 0.10 \text { leve } \\
* * \text { Significant at the } 0.05 \mathrm{lev}\end{array}$ & & & & & & & & \\
\hline
\end{tabular}

Chi-square tests indicate there are no significant differences in the social characteristics across the four samples. The binomial logit model was adapted to analyze the CVM data. For simplicity of analysis, no social characteristic variables were included. The results of the CVM study for both areas are shown in Table 5. In both samples, coefficients of COST are negative, which suggests that people are likely to accept the policy which has a lower cost to households. However, COST in the Canterbury sample and the model overall is insignificant, while for the rest of New Zealand it is found to be significant.

Choice modeling results were analyzed with the conditional logit model using effect codes (Louviere, David, and Joffre, 2000) rather than dummy variables for the four ES attributes. Definitions of the effect codes for attribute variables are presented in Table 6 . The advantage of using effect codes over dummy variables is the ability to observe a respondent's comparison of one level with other levels in an attribute (Takatsuka, 2004).

Table 6. Effect Codes: Choice Modeling

\begin{tabular}{lll}
\hline Attributes & Variables & \\
\hline Green House Gas Emissions & GGS & 1 if small reduction $; 0$ if big reduction ; -1 if no change \\
& GGB & 1 if big reduction; 0 if small reduction; -1 if no change \\
Nitrate Leaching & NLS & 1 if small reduction $; 0$ if big reduction ; -1 if no change \\
& NLB & 1 if big reduction; 0 if small reduction; -1 if no change \\
Soil Quality & SOIL & 1 if small change; -1 if no change \\
Scenic Views & SV & 1 if more variety; -1 if no change \\
Cost to Household & COST & NZ $\$ 10 ; \$ 30 ; \$ 60 ; \$ 100$ \\
\hline
\end{tabular}


Table 7. Conditional Logit: Choice Modeling with ASC

\begin{tabular}{|c|c|c|c|c|c|c|c|c|}
\hline & \multicolumn{4}{|l|}{ Canterbury } & \multicolumn{4}{|l|}{ Rest of NZ } \\
\hline & Coeff. & Std.Err. & t-ratio & P-value & Coeff. & Std.Err. & t-ratio & P-value \\
\hline$\overline{\mathrm{COST}}$ & $-0.011 * *$ & 0.002 & -5.889 & $3.897 \mathrm{E}-08$ & $-0.013 * *$ & 0.002 & -6.565 & $5.22 \mathrm{E}-11$ \\
\hline GGS & $0.084 * *$ & 0.046 & 1.824 & 0.068 & $0.176 * *$ & 0.049 & 3.552 & 0.0003822 \\
\hline GGB & $0.479 * *$ & 0.055 & 8.638 & $2.887 \mathrm{E}-15$ & $0.309 * *$ & 0.059 & 5.262 & $1.42 \mathrm{E}-07$ \\
\hline NLS & $0.222 * *$ & 0.052 & 4.246 & $2.178 \mathrm{E}-05$ & $0.118 * *$ & 0.056 & 2.091 & $3.65 \mathrm{E}-02$ \\
\hline NLB & $0.358 * *$ & 0.051 & 6.992 & $2.712 \mathrm{E}-12$ & $0.456 * *$ & 0.056 & 8.168 & $2.89 \mathrm{E}-15$ \\
\hline SOIL & $0.233 * *$ & 0.040 & 5.782 & 7.387E-09 & $0.194 * *$ & 0.043 & 4.493 & 7.01E-06 \\
\hline SV & $0.088 * *$ & 0.034 & 2.559 & 0.010 & $0.072 * *$ & 0.036 & 2.006 & 0.045 \\
\hline A_01 & 0.132 & 0.207 & 0.637 & 0.524 & $0.602 * *$ & 0.224 & 2.687 & 0.007 \\
\hline A_02 & 0.145 & 0.131 & 1.102 & 0.270 & $0.479 * *$ & 0.142 & 3.374 & 0.001 \\
\hline Number of observation & 2075.000 & & & & 1809.000 & & & \\
\hline Chi-squared & 190.352 & & & & 163.220 & & & \\
\hline Log-likelihood & -2006.260 & & & & -1717.536 & & & \\
\hline R-squared Adj. & 0.043 & & & & 0.040 & & & \\
\hline $\begin{array}{l}* \text { Significant at the } 0.10 \\
* * \text { Significant at the } 0.0\end{array}$ & & & & & & & & \\
\hline
\end{tabular}

Table 7 shows the choice modeling results, including that of alternative specific constants (A-01, A02), which present unobserved factors on respondent's choices (Morrison, 2002). All variables are significant at the 0.05 level, except for A-01 and A-02 in the Canterbury sample, which can be interpreted as New Zealand people are willing to pay for improvements in levels of all four of these attributes. Big reductions in greenhouse gas emissions and of nitrate leaching have large magnitude coefficients for both the Canterbury residents and those who live in the rest of New Zealand. On the other hand for both sample strata, the coefficients of scenic views are relatively lower than for the other variables.

Welfare values for the various policy alternatives described in the survey are estimated by using equation (7) and the results are shown in Table 8. The CVM survey provides an estimation of a single policy value from one CVM question that involves a 50\% reduction of greenhouse gas emissions from cropping farms. The choice modeling results, on the other hand, elicit economic values for six policy alternatives, because the model can estimate multiple policies simultaneously from multiple choice sets. 
Table 8. Willingness-to-pay

\begin{tabular}{|c|c|c|c|c|c|c|c|c|}
\hline & $\begin{array}{l}\text { GG- } 20 \% \\
\text { reduction }\end{array}$ & $\begin{array}{l}\text { GG- } 50 \% \\
\text { reduction }\end{array}$ & $\begin{array}{r}\text { NL-20\% } \\
\text { reduction }\end{array}$ & $\begin{array}{r}\text { NL- } 50 \% \\
\text { reduction }\end{array}$ & $\begin{array}{l}\text { SOIL- } \\
\text { change }\end{array}$ & $\begin{array}{r}\text { SV- } \\
\text { variety }\end{array}$ & $\begin{array}{r}\text { Stated } \\
\text { Ideal }\end{array}$ & $\begin{array}{r}\text { Estimated } \\
\text { Ideal }\end{array}$ \\
\hline \multicolumn{9}{|l|}{ CVM } \\
\hline Canterbury & & 192.51 & & & & & 48.89 & \\
\hline Rest of NZ & & 86.03 & & & & & 59.08 & \\
\hline \multicolumn{9}{|c|}{ CHOICE (With ASC) } \\
\hline Canterbury & 60.52 & 97.36 & 74.95 & 87.73 & 43.49 & 16.43 & 63.04 & 245.02 \\
\hline Rest of NZ & 50.72 & 60.96 & 53.10 & 79.03 & 29.81 & 11.08 & 55.25 & 209.92 \\
\hline \multicolumn{9}{|c|}{ GG - Greenhouse gas emissions } \\
\hline \multicolumn{9}{|c|}{ NL - Nitrate leaching } \\
\hline \multicolumn{9}{|c|}{ SOIL - Soil quality } \\
\hline SV - Scenic V & & & & & & & & \\
\hline
\end{tabular}

From the CVM samples, mean values of the policy for a 50\% reduction of greenhouse gas emissions are NZ\$192.51 and NZ\$86.03 in Canterbury and the rest of New Zealand respectively. The value for the Canterbury sample derived from the CVM surveys is nearly double the value of the same policy from the choice modeling samples.

The results of welfare values from the choice modeling demonstrate that for Canterbury residents, the policy for a big reduction of greenhouse gas emissions is valued at $\$ 97.36$ in the model, which is the highest value among the six policy alternatives. The following policies are ordered from second highest to lowest: big reduction of nitrate leaching; small reduction of greenhouse gas emissions; small reduction of nitrate leaching; soil quality change; and scenic view change. For the 'rest of New Zealand' sample strata, the highest valued policy is a big reduction in nitrate leaching, and the rank order of the remaining policies is: big reduction of greenhouse gas emissions; small reduction of nitrate leaching; small reduction of greenhouse gas emissions; soil quality change; and scenic view change. The order of respondent's willingness to pay for the six policy alternatives is the same in both samples.

The survey questionnaires asked respondents about their ideal level of each attribute and ideal cost to their own household. The mean cost to households for their ideal policies were NZ\$63.04 and NZ\$55.25 for the Canterbury stratum and the rest of New Zealand respectively, and the distribution from choice samples in both areas are presented in Table 9. For both samples, respondent's most 
preferred levels are a big reduction of greenhouse gas emissions, a big reduction of nitrate leaching, small change in soil quality, and more variety in scenic views.

Table 9. Ideal Policies: Choice Modeling

\begin{tabular}{|c|c|c|c|c|c|c|c|c|c|c|c|}
\hline \multicolumn{12}{|l|}{ Canterbury } \\
\hline & $G G$ & $\%$ & & $N L$ & $\%$ & & SOIL & $\%$ & & $S V$ & $\%$ \\
\hline No Change & 414 & 7 & No Change & 297 & 5 & No Change & 708 & 12 & No Change & 2592 & 44 \\
\hline Small Change & 2160 & 36 & Small Change & 1932 & 32 & Small Change & 5265 & 88 & More Variety & 3366 & 56 \\
\hline Big Change & 3450 & 57 & Big Change & 3801 & 63 & & & & & & \\
\hline Total & 6024 & 100 & & 6030 & 100 & & 5973 & 100 & & 5958 & 100 \\
\hline
\end{tabular}

\begin{tabular}{|c|c|c|c|c|c|c|c|c|c|c|c|}
\hline & $G G$ & $\%$ & & $N L$ & $\%$ & & SOIL & $\%$ & & $S V$ & $\%$ \\
\hline No Change & 321 & 6 & No Change & 204 & $\overline{4}$ & No Change & 696 & 13 & No Change & 2354 & 46 \\
\hline Small Change & 1935 & 37 & Small Change & 1410 & 27 & Small Change & 4500 & 87 & More Variety & 2764 & 54 \\
\hline Big Change & 2991 & 57 & Big Change & 3621 & 69 & & & & & & \\
\hline Total & 5247 & 100 & & 5235 & 100 & & 5196 & 100 & & 5118 & 100 \\
\hline
\end{tabular}

Welfare values of the ideal levels of the policies are estimated using choice modeling. The results show that the willingness-to-pay for the ideal policy combination is NZ\$245.02 per household per annum for Canterbury and NZ\$209.92 per household per annum for the rest of New Zealand (see Table 8).

\section{Summary}

The current CVM study estimated welfare values for a significant reduction of greenhouse gas emissions from arable lands for people living in (i) Canterbury (the region with the most arable farms) and (ii) the rest of New Zealand. Compared to the choice modeling results, the values derived from the CVM study are higher for the same policy. The high value may be due to the insignificant COST variable in the CVM Canterbury sample, however, the value derived from the CVM for the rest of New Zealand also exhibits a larger value than the estimate derived from the choice modeling. There may be embedding issues; respondents may not have clear boundaries between ES attributes and hence may overestimate the value of a single attribute. 
This concern also appears in the study of respondent's ideal policy. The mean stated ideal cost to households for their preferred policies are much lower than the mean values of the ideal policy estimated by choice modeling. The choice modeling approach can estimate values of multiple attributes simultaneously. The assumption is that each attribute has its own separate bundle and value. However, respondents did not seem to behave in this manner in this study. It is an open question whether the values for the ideal policy derived by the choice modeling reflect people's true willingness to pay. This methodological issue requires further investigation.

The results of the choice modeling show that people in both areas have high willingness to pay for a big reduction of greenhouse gas emissions and nitrate leaching from arable farms. In other words, the value of selected ES is significant in New Zealand cropping farming. These results differ significantly from the global study of Costanza et al., (1997) and the New Zealand and Waikato ES values reported by Patterson and Cole (1999a, 1999b). Each of which suggested few ES were valuable for arable land.

Our study has illustrated that people in Canterbury are more concerned about greenhouse gas emissions than they are about other attributes, but people in the rest of New Zealand are more willing to pay to improve water quality that is impaired by arable farming. The value of maintaining soil quality is higher for Canterbury respondents than that for the rest of New Zealand respondents. Greater public knowledge in Canterbury of wind erosion and soil quality issues may influence Canterbury residents to assign higher values for these items than those assigned by respondents from elsewhere in New Zealand. The values of scenic views of arable farms are positive although the ES is not directly related to ecosystem functioning and is likely to be ignored in management policies on arable land. The result shows that improving landscape of arable lands would enhance social welfare for people in the study regions. This ES attribute appears to provide a modest component of the total social benefits that are derived from New Zealand arable lands. 
The results of this study identify that the two regions in New Zealand need different strategies to improve selected ES to maximize their respective regional welfare. These findings will be useful in developing policies to achieve sustainable arable farming in New Zealand. One concern of this study is the external effects of ES beyond each arable farm's boundary as those effects are likely to be overlooked by arable farmers. Further study is required to determine if land use policies relating to arable farming need modification to achieve greater recognition of these ES. Similar research can be

completed for other engineered ecosystems, particularly for pastoral land (the largest agricultural land use in New Zealand) (Baskaran, et al., 2009) and for horticultural land as these have recently become the subject of considerable public attention. The study of the welfare effects of ES delivered by agricultural lands could provide important insight into the management of engineered or designed ecosystems.

\section{Acknowledgement}

This project is financially supported by the New Zealand Foundation for Research, Science \& Technology (LINX0303).

\section{References}

Baskaran, R., Cullen, R., and Takatsuka, Y. (2009) Estimating the Value of Agricultural Ecosystem Service: A case study of New Zealand Pastoral Farming. Australasian Journal of Environmental Management 16(2), 103-112.

Ben-Akiva, M., and Lerman, S. (1985) Discrete Choice Analysis. Cambridge, MA: MIT.

Boxall, P., Adamowicz, W., Swait, J., Williams, M., and Louviere, J. (1996) A Comparison of Stated Preference Methods for Environmental Valuation. Ecological Economics 18, 243-253. 
Costanza, R., d'Arge, R. de Groot, R., Farber, S., Grasso, M., Hannon, B., Limburge, K., Neem, S., O’Neil, R., Parelo, J., Raskin, R., Sutton, P., and van den Belt, M. (1997) The Value of the World's Ecosystem Services and Natural Capital. Nature 387, 253-259.

Daily, G., Matson, P., and Vitousek, P. (1997) Ecosystem Services Supplied by Soil. In: Gretchen, D. (ed.) Nature's Services: Society Dependence on Natural Ecosystem. Washington DC: Island Press.

Glendining, M., Dailey, A., Williams, A., van Evert, F., Goulding, K., and Whitmore, A. (2009) Is It Possible to Increase the Sustainability of Arable and Ruminant Agriculture by Reducing Inputs? Agricultural Systems 99, 117-125.

Greene, W. (2002) Limdep Version 8.0 Economic Modeling Guide Volume 2. New York: Econometric Software, Inc.

Haab, T. and McConnell, K. (2003) Valuing Environmental and Natural Resources.

Cheltenham: Edward Elgar.

Heal, G. and Small, A. (2002) Agriculture and ecosystem services. In:

Gardner, B. and Rausser, G. (eds.) Handbook of Agricultural Economics Vol. 2a. Amsterdam: North Holland.

Huber, J. and Zwerina, K. (1996) The Importance of Utility Balance in Efficient Choice Designs. Journal of Marketing Research 33 (3), 307-317.

Hughey, K., Kerr, G., and Cullen, R. (2004) Public Perceptions of New Zealand's Environment: 2004. Lincoln: EOS Ecology. 
Louviere, J, Hensher, D., and Swait, J. (2000) Stated Choice Methods. Cambridge, UK.

Millennium Ecosystem Assessment. (2003) Ecosystem and Human Well-Being: Framework for Assessment. Washington DC: Island Press.

MAF Policy. (2009) available on <http://www.maf.govt.nz/mafnet/rural-nz/profitability-andeconomics/contribution-of-land-based-industries-nz-economic-growth/contribution16.htm>.

Moonen, A and Barberi, P. (2008) Functional Biodiversity: An Agroecosystem Approach. Agriculture, Ecosystems and Environment 127, 7-21.

NIWA. (2007) Stocktake of Diffuse Pollution Attention tools for New Zealand Pastoral farming Systems. NIWA Client Report: HAM2007-161. National Institute of Water \& Atmospheric Research Ltd. Hamilton, New Zealand.

Parliamentary Commissioner for the Environment. (2004) Growing for good: Intensive farming, sustainability and New Zealand's environment. Wellington: Parliamentary Commissioner for the Environment.

Patterson, M. and Cole, A. (1999a) Estimation of the value of ecosystem services in the Waikato Region. Hamilton: Environment Waikato Regional Council.

Patterson, M. and Cole, A. (1999b) Assessing the Value of New Zealand's

Biodiversity. School of Resource and Environmental Planning. Palmerston North: Massey University. 
Pretty, J. Mason, F., Nedwell, D., Hine, R., Leaf, S., and Dils, R. (2003) Environmental Costs of Freshwater Eutrophication in England and Wales, Environmental Science and Technology 37 (2), 201-208.

Pyke, Nick. (2008) Arable farming: Are We Green Enough? FAR Newsletter 53, 1.

Takatsuka, Y. (2004) Comparison of the Contingent Valuation Method and the Stated Choice Model for Measuring Benefits of Ecosystem Management. PhD Dissertation, Available on $<$ http://etd.utk.edu/2004/TakatsukaYuki.pdf, Knoxville: University of Tennessee> .

Terawaki, T., Kuriyama, K., and Yoshida, K (2003) The Importance of Excluding Unrealistic Alternatives in Choice Experiment Designs, Discussion Paper No. 03002, College of Economics, Kyoto: Ritsumeikan University. 


\section{Appendix}

A. A sample question in a CVM Survey

Please tick the option that you prefer:

\begin{tabular}{|c|c|c|}
\hline & Option A & Option B \\
\hline \hline $\begin{array}{c}\text { Greenhouse } \\
\text { Gas Emission }\end{array}$ & Big Reduction & No Change \\
\hline $\begin{array}{c}\text { Nitrate } \\
\text { Leaching }\end{array}$ & No Change & No Change \\
\hline Soil & No Change & No Change \\
\hline Scenic Views & No Change & No Change \\
\hline $\begin{array}{c}\text { Cost to } \\
\text { Household } \\
\text { (\$ per year for } \\
\text { next 5 years) }\end{array}$ & $\$ 60$ & $\$ 0$ \\
\hline
\end{tabular}

Option A

Option B

B. A sample question in a Choice Modeling Survey

Please tick the option that you most prefer:

\begin{tabular}{|c|c|c|c|}
\hline & Option A & Option B & Option C \\
\hline \hline $\begin{array}{c}\text { Greenhouse } \\
\text { Gas Emission }\end{array}$ & Big reduction & No change & No change \\
\hline $\begin{array}{c}\text { Nitrate } \\
\text { Leaching }\end{array}$ & Big reduction & $\begin{array}{c}\text { Small } \\
\text { reduction }\end{array}$ & No change \\
\hline Soil & No change & No change & No change \\
\hline Scenic Views & More variety & No change & No change \\
\hline $\begin{array}{c}\text { Cost to } \\
\text { Household } \\
\text { (\$ per year for } \\
\text { next 5 years) }\end{array}$ & $\$ 100$ & $\$ 10$ & $\$ 0$ \\
\hline
\end{tabular}

Option A

Option B

Option C 